\title{
Veline, ordinary women and male savages: Disentangling racism and heteronormativity in contemporary narratives on sexual freedom
}

\author{
Alessandra Gribaldo* \\ School of Foreign Languages and Literatures, Translation and Interpretation, \\ University of Bologna, Forlì, Italy
}

(Received 10 July 2017; final version accepted 19 December 2017)

\begin{abstract}
This article takes as its starting point the so-called 'sex scandals' surrounding Italy's former prime minister Silvio Berlusconi during the last years of his premiership (2009-2011), which have filled Italian newspaper columns and legal case files. Political discourses and media interpretations of women's freedom at the time represented genders through the eroticisation of power. The deployment of postfeminist and stereotyped representations of gender relations produced a complex and ambivalent frame for female sexuality and agency which reproduced the hegemonic neoliberal rhetoric that locates freedom and emancipation in the market. This narrative was further inflected by class and race, as it was deployed through the opposed images of white, Italian, respectable, caring women, and cynical young women and migrants using their bodies as a resource in a sexual-economic exchange with men occupying positions of power. Through feminist reflections on work I frame and discuss the use of the notions of choice and freedom in these discourses. Shifting the focus from women's behaviour to the analysis of a peculiar image of masculinity displayed by the then premier, the article highlights how racism, colonial legacies and homophobia are enmeshed in this historically and culturally based gender imagery.
\end{abstract}

Keywords: Sexism; racism; heteronormativity; sexuality; gender

\section{Introduction}

In the spring of 2009, Italy's then prime minister Silvio Berlusconi became involved in scandals for allegedly having ensnared women, escorts ${ }^{1}$ and aspiring veline $e^{2}$ in private settings (meetings, parties and dinners), requesting sexual services in exchange for promises of television appearances or political positions. Berlusconi and his lawyers described these encounters, that supposedly took place at night in the premier's private residence in Arcore, ${ }^{3}$ merely as 'elegant dinners'. Yet the investigations and criminal proceedings (some of them still underway) ${ }^{4}$ suggested the presence of a brisk sex-money-power exchange revolving around the former prime minister, with gender, sexuality and desire at its core. In the media 'sex scandals' became synonymous with this system of exchange, and the idea of prostitution within the seats of power raised a general moral and political debate about women's use of sexuality.

The almost 20 years of Berlusconi's political presence in Italy ${ }^{5}$ is strongly rooted in the media empire he established, which helped to strengthen and expand his political, social and economic influence. His peculiar personal and mediatic communicative style can be described as

*Email: alessandra.gribaldo2@unibo.it 
'anti-political': his success as a leader has relied heavily on his capacity to interpret people's gut feelings following the mood of the time (Pasquino 2007, 50). In the figure of the former premier, the seductive, affective and corporeal in some ways encompass and overwhelm the political (Belpoliti 2009, Dei 2011). Part of his popularity relied on the revamping of a conservative discourse and 'commonsense' feeling about gender relations and gender roles, sex, and female freedom, which developed during the 1980s in reaction to the achievements of the women's movement achievements of the previous decade. In particular, it represents the unbalanced male/female relations of power as ahistorical and ancestral and, consequently, as the quintessential naturalised foundation of all social hierarchies (Tabet 2004). Power imbalances are therefore essentialised and conflict minimised. The efficacy of this discourse is compounded by a neoliberal view of individual agency and self enterpreneurship: freedom to make use of one's own attractiveness is viewed as a valuable capacity in a competitive market society (Dominijanni 2014, Morini 2010).

The mainstream debate on women's freedom, though designed to combat these narratives, has actually produced normative views of gender difference. In particular, despite the complexity of stances within feminist, LGBTQI ${ }^{6}$ and women's movements in Italy (Romagnoli 2014), a quite moralistic view of the sex-money exchange took hold. In particular the newly-established women's movement Se Non Ora Quando (If Not Now When) - known as SNOQ - saturated the media with claims and messages that suggested a dichotomy between respectable women who do not lend themselves to this exchange and cynical women who do, and who seek it.

In this article I wish to foreground the centrality of gender, and specifically representations of femininity and of naturalised gender imbalances of power, underlying the mediatic-political scenario of recent years in Italy. To analyse these discourses I refer to contemporary newspaper articles reporting events, interviews with protagonists, and opinions and comments, foregrounding the cultural meanings related to gender construction. I will suggest how the complexity of debates on the meanings of female freedom can be better understood by untangling several implicit dimensions. One of these revolves around the meaning of coercion and choice in sexual-economic exchange. Another reflects the changes in the sphere of work in recent times and how body and relationality have been put to work. Finally, I look at how race, class, and sexuality fracture the category of women and contribute to the discursive construction of a peculiar form of masculinity. In this way I propose a more substantial discussion on agency and female freedom, in a context in which the political meaning of these notions is appropriated by neoliberal discourse (Fraser 2013).

In the first part of the article I discuss the devices that naturalise and essentialise the difference between male and female sexuality, and how, in Italy, they echo the neoliberal-driven equation of market and personal freedom. The second section addresses the dichotomy between valuable family women seen as the vestal guardians of the nation (Yuval-Davis 1997) and those who use their sexuality outside of the sphere of affectivity and shift it to the market, which traversed the pronouncements of SNOQ. Finally, in the last section I highlight how these narratives were imbued with racism and homophobia, through an analysis of the then premier's self-portrayal.

\section{Sexual freedom and sexual-economic exchange}

Starting from their coverage of Patrizia D'Addario - the woman who first spoke out regarding Berlusconi and his entourage's practices to demand sex in exchange for power and money ${ }^{7}-$ Italian newspapers devoted many column inches from 2009 to 2011 both to the ensuing judicial investigations and to the declarations of diverse figures involved in the events, especially young women.

'If you are ugly, you might as well stay at home. It has always been this way, from the very beginning [...] this is the way it is and should be. ${ }^{, 8}$ With these words, Terri De Nicolò - an Italian 
woman who worked as an escort, and who was involved in the sex scandals - responded to the criticisms and the moral judgment of the media against the beautiful young women surrounding Berlusconi and his entourage, which she ascribed to resentful and less charming women. Her words fed into the political discourses that aimed to normalise Berlusconi's sexuality as a private behaviour rather than an issue of public concern. More importantly, they expressed both women's claim to use their attractiveness as a resource, and the dominant narratives regarding gender relations and sexual freedom in Italy during the period of Berlusconi's political rule. Gender relations here appear to reflect a naturalised sexuality (Mathieu 2013, Tabet 2004). Masculinity is characterised by the predatory (hetero)sexual drive, while femininity is marked by the careful, prudent and strategic management of her sexed body as a resource. This stance resonates with Hakim's concept of 'erotic capital' (2011), which essentialises the existence of qualitative differences in male and female sexuality: inasmuch as men are conceived as naturally being in need of more sex than women, the latter's attractiveness and seduction amount to a form of (erotic) capital which they can use for their own means. In this evolutionary Darwinian narrative, the strongest and wealthiest men and the most beautiful and astute women win out.

The words of De Nicolò reflect the endorsement of this 'ancestral' truth and ahistorical narrative of the survival of the fittest, which at the same time is intertwined with postfeminist ${ }^{9}$ and neoliberal discourses about women's agency, freedom and self-fashioning (Gill and Scharff 2011, McRobbie 2009). These narratives posit that once the patriarchal restrictions that constrained female sexuality through kinship structures (Rubin 1975) fade away, women, having finally achieved liberation, are able to freely manage their own bodies and sexuality. Hence, they align themselves to the contemporary neoliberal narrative which posits that women's freedom and the free market are one and the same (Gill 2007, Phillips 2013). Yet these triumphalist views conceal the fact that choice, gender and freedom are entangled in complex ways, where agency means action but is also an effect of socio-economic and cultural determinations. If agency and spaces of negotiation can also be found in contexts of subjection, recent works have highlighted the need to frame agency together with coercion and subordination, locating female subjectivity at the core of the reflection (Madhok, Phillips and Wilson 2013, Mahmood 2005).

As the anthropologist Paola Tabet has illustrated, female sexuality is granted definition through the very sexual-economic exchange. The social construction of women's weaker or less urgent sexual desire and lower economic power than men turns their sexuality into a resource, which women can exchange against a compensation (status, gifts, money) within a continuum of sexual-economic exchanges between the sexes encompassing the opposite poles of marriage and prostitution. The concept of the continuum questions the ideological separation between the category of prostitutes and that of respectable women, wives and mothers (Tabet 2004). In this view, women's management of their sexuality often frees them from the marriage bond, which presupposes their permanent sexual services as well as domestic reproductive and working tasks. Hence Tabet shows that sexuality as a service is neither universal nor natural; rather, it must be viewed as a historical and political terrain of conflict between the sexes.

In Berlusconi's narrative, however, the sexual-economic exchange underlying the sex scandals appeared to follow a natural game, encompassing seduction, romance and marriage. For example, when during a TV programme a young, precariously employed female worker told him about the difficulties young people face in starting a family, the then premier ironically suggested that since she had a beautiful smile, she could 'marry well'. ${ }^{10}$ In declaring the absolute legitimacy and normality of locating a woman's personal beauty within a marriage market, Berlusconi's words invited the placing of instrumentality at the core of intimate choices. Yet this is disguised under the name of marriage or romantic encounter, and the object of the transaction between the 
sexes - whether money, status, power or protection - is never explicitly mentioned. Indeed, the escorts and aspiring showgirls attending the 'elegant dinners' hosted at the former prime minister's mansion at Arcore never defined the reward they received for their participation as a remuneration. They speak of gifts, favours, a trip in a private jet, promises to appear and occupy well-paid positions on Berlusconi's TV channels, assistance in launching a home business. The most significant recurrent expression is 'monetary gift', ${ }^{11}$ which negates the underlying deal and exchange, and rather frames the young woman as a participant in a free encounter characterised by mutual seduction. The gifting relationship is depicted as an act of graciousness, the reward is a present not established beforehand. In this way young women avoided the stigma of prostitution and men appeared as seductive gentlemen.

In this sense, the sex-for-money exchange taking place in the seats of power is the opposite of the demands made by the Italian Comitato per $i$ diritti civili delle prostitute (Committee for prostitutes' civil rights): to make explicit the economic agreement, to decide the terms and the object of the exchange, and to put a price on each service - whether a simple sexual act, or expressions of emotional support or affection (Corso and Landi 1991). More generally, through their work experiences and collective reflections, sex workers have succeeded in developing a language which reveals the power relations between customers and service providers. They have been able to make claims and engage in collective political action in diverse contexts around the world, upholding rights and resisting marginalisation and exploitation (Pheterson 1989, Kempadoo and Doezema 1998).

Conversely, the women involved in the sex scandals frequently adhered in public to the neoliberal narrative, describing their encounters as if they represented an exchange among equally positioned market agents. In this way, they also concealed that they did not arrange their services directly with the client, but rather through a plethora of intermediaries. In part, their compliance with this narrative reflects the specificities of the prostitution law in Italy, which criminalises any form of third-party mediation. ${ }^{12}$ In this context, the 2008 (failed) legislative proposal to criminalise the sale and purchase of outdoor sexual services can be read as the flip side of the legitimisation of the sexual-economic exchange which women can discreetly mobilise to gain access to money and seats of power (Signorelli 2011). If young women are advised to pursue a good marriage ('marry well') as an economic investment, then prostitution can be disguised as a form of romantic encounter.

The production of gender relations - conservative and neoliberal at the same time - at play during the 'elegant dinners' at the Arcore mansion is constantly being re-staged. Indeed, these encounters are not about sex alone; the sexual act is only the final step, the consummation of a series of performative rites enacting the parties' participation in an unequal exchange between the sexes. In these settings young women were called upon to confirm and reproduce masculine desire and economic power. Newspaper reports on wiretapped conversations among some of the women involved revealed their awareness of the mise-en-scène they were expected to perform: ${ }^{13}$ from mandatory laughter at jokes, to the use of friendship-evoking expressions of intimacy and affection as well as vertical kinship terms (e.g. papi, meaning 'daddy', to refer to Berlusconi). ${ }^{14}$

The words of the women involved in the sex scandals reveal a mixture of awareness, postfeminist claims of agency and 'expertise' in navigating the difficult struggle to access the desired resources and status: negotiating their availability, managing the intermediaries, claiming the conscious use of their own bodies and erotic capital. In most cases, they appear to be trapped between the claim of using their sexuality as they wish, and the effort to escape the indelible stigma of prostitution. This helps to explain why their public statements abound with contradictions: their 'great friendship' with the prime minister does not prevent them from asking for an 
'attendance fee'. Structurally and naturally pre-established gender relations are viewed as freely and equally constituting the social sphere, where the heterosexual, 'natural' attraction is thus the taken-for-granted nucleus, the epitome of society as a whole. In the interpretation of the neoliberal idea of freedom within an unpredictable market, this vision of relations between the sexes has come to represent a reassuring bedrock. Hence, the supposedly unlimited range of possibilities that neoliberalism describes is actually constrained within the natural sexual differences on which the sexual-economic exchange is based: all is free and unrestrained except gender roles and sexed bodies. This ambivalence makes evident the convergence between neoliberal and conservative discourses on women's freedom and highlights how women are identified as a category which is both normative and essentialised. In the next section I wish to show that a similar normalising risk in defining women's freedom can be traced in emancipatory and progressive narratives produced against neoliberal and conservative stances during the last years of the Berlusconi government.

\section{Ordinary working mothers, image-girls and the feminisation of work}

On January 18, 2011 the then director of the leftist newspaper L'Unità launched a call to action against the sexism embedded in and reproduced through Italy's political apparatus and pro-gender equality politics, which she formulated as follows:

I am sure, I know for a fact that the majority of Italian women are not queuing up for bunga bunga [the name given to the night-time parties at Arcore - see next section]. I am certain that consciously exercised prostitution is the choice, if one can indeed speak of a choice under such conditions, of a small minority. It is thus to the others, all the other women, that I address my words. It is time to make yourselves heard: where are you, girls? Mothers, grandmothers, daughters, granddaughters, where are you? ${ }^{15}$

Written amidst the mounting sex scandals, this call became a manifesto signed by well-known Italian women working in politics, academia and the media. It was signed by over 50,000 people and led to the organisation of numerous demonstrations in various cities in Italy. ${ }^{16}$ The explicit aim of the promoting committee, named Se Non Ora Quando (SNOQ), was 'to set together the political agenda of Italian women ${ }^{17}$ and to propose concrete gender-equality policy measures such as maternity allowance, mandatory paternity leave, and norms to safeguard women's work, against the common practice of asking women to sign an undated letter of resignation. The call criticised the Berlusconian imaginary of gender relations which emerged during the sex scandals, and particularly expressed 'women's scorn against a premier who, through politics and behaviour, betrayed women's dignity' (ibid.). It also foregrounded a sheer opposition between dignity and prostitution, by casting women who offer themselves for this exchange (i.e. those 'queuing up for bunga bunga') in opposition to those who do not (i.e. women who care about their own personal dignity). The references deployed expressed a nostalgic and normative view of women's respectability that essentialises the 'true' nature of femininity and motherhood. Hence they invoke a familial everydayness, hailing women in kinship positions revolving around a male ego, such as wives, mothers, sisters and daughters (Pitch 2011, Nadotti 2011, Dominijanni 2014). This move to distinguish between 'respectable' and 'non-respectable' women inevitably conceals the complexity of the knot surrounding the sex-for-money exchange, as illustrated by Tabet, and reads the exchange as something that women must not get involved in if they want to retain their dignity. ${ }^{18}$

As this article has shown so far, the public debates during the sex scandals presented two competing discourses. On the one hand, women participating in the exchange of sex for power and money laid claim to their right to use their own bodies and sexuality, with media attention focused 
on their tastes, excessive habits of consumption and presumed lack of awareness. On the other hand, SNOQ's narrative focused on the notion of women's dignity, a feature of down-to-earth, ordinary women set against the eroticised and commodified image embodied by the veline portrayed in the president's TV channels. Hence femininity emerges as a frame within which opposing behavioural models square off: excess, unrestrained pleasure, hyper-consumption, superficiality and selfishness versus responsibility, sacrifice, selflessness and austerity.

Yet in addition to yoking respectable femininity to the domestic, familial and heterosexual sphere, this polarisation erases a generational rupture. This female 'normality' applies by and large to middle-class women who came of age at a different historical moment, during Italy's economic boom. Today, the conditions of economic precariousness burdening an entire generation (Fantone 2007, Galetto et al. 2009) make it more difficult for younger women to gain access to the female 'normality' and 'dignity' vaunted by women of more economically protected social groups.

It is not only that the body and sexuality are resources to fall back on for the more unprotected current generation of women. Sexuality, intimacy and seduction have become a privileged site of production in global economies and inhabit new market niches (Hoang 2015, Bernstein 2007). The post-Fordist model of production, taking hold towards the end of the last century, is characterised by an increasingly optimised relationship between the spheres of work and consumption. The new productive paradigm emphasises the role of abstract knowledge and social cooperation, within which individuals feature not only as workforce but also as social and communicative beings. Their communicative and relational capacities, as well as the sphere of feelings and emotion, are all turned into productive work (Marazzi 1999). This new form of capitalist appropriation of the intimate leads to an unprecedented form of exploitation.

In an essay that puts post-Fordist theories on work in dialogue with feminist studies, Cristina Morini has highlighted that within neoliberalism the sphere of affect and sexuality is put to work, and that historically invisible, unpaid and unrecognised reproductive work has become the epitome of the contemporary work mode (2010). When life time and work time coalesce, women's conditions of reproductive work ${ }^{19}$ have become the rule of emerging working conditions: the care-related, affective, emotional and relational dimension represents the intimate side of production, where subjectivity itself is moulded to participate in the productive system. Indeed, to appear desirable on the job market, workers need not only technical skills, but also that set of qualities that are commonly associated with women - dedication, availability, the ability to seduce and to take care of others. This system of production conflates the role of the escort, the velina, the housewife, and the caregiver, in which selling one's labour power means offering up personal and relational capacities, such as emotions, care, and intimacy (Morini 2007, 2010).

The figure of the escort, the latest sophisticated version of the entraineuse, has emerged as a paradigmatic figure of the exploitation of bodies and skills characteristic of contemporary times. In fact, she perfectly expresses the invasiveness of the production apparatus and the trend of putting to work not only a worker's body but also her subjectivity, that must be flexible, available, marketable, tailor-made. The figure of the 'image girl' offers another such instance. This term was used by the women attending the prime minister's 'elegant dinners' to define themselves, as well as by the intermediaries and the media (Dominijanni 2009), and it is a neologism for a young woman who is employed to entice clients, by means of her pleasant appearance, into nightclubs, trade shows, or merchandising and selling exhibitions. The image girl is a sort of intermediate figure between a model and an escort, a figure in which image, body and merchandise overlap. Thanks to the flexibility, opaqueness and ambivalence of her role, she can fulfil diverse tasks, ranging from her simple presence to sexual services. Market demands fetishise the individual's 
quality of self-ownership as if the ability to manage one's own body and image automatically constituted a form of power. As Gill puts it: 'could it be that neoliberalism is always already gendered, and that women are constructed as its ideal subjects?' $(2008,443)$.

This zone of opacity between work and life, neoliberal market demands and subjectivity can also be traced in the gender imagery characterising the night-time parties in the former prime minister's mansion, as emerging from the words of a testimony reporting that women were required to dress up as policewomen, nurses or teachers. ${ }^{20}$ This request recalls the 1970s Italian popular soft porn movies ${ }^{21}$ that eroticised women's newly acquired professional roles, amounting to a sort of cinematic chauvinist response to the gains of women's movements and increasing female participation in the labour market. Indeed, the carnivalesque character of these supposedly 'elegant dinners' obscures the underlying symbolic violence that reinterprets women's work as invariably sexual and seductive. The article also reports the case of a woman who was made to dress up as a nurse, but who actually worked as a nurse. A real nurse asked to dress up as a nurse: this is a condensation of the figure of 'emancipated woman' who is at one and the same time a playful mask, a professional figure, a sexually liberated woman, a prostitute and a caregiver within a deeply rooted proto-pornographic TV imaginary.

The tension between the notions of women's free choice and coercion, therefore, emerges clearly from an analysis of the narratives and the imagery revolving around the sex scandals. Behind the issue of women's freedom there is the complicated frame of the changing forms of neoliberal rhetoric of choice and post-Fordist market demands.

In the next section I shift the focus from female sexuality to male sexuality, to discuss the kind of masculinity that was implied in this gendered imagery. In particular I analyse the self-portrayal of Berlusconi and the public debate around his sexual behaviour, showing how they are permeated with issues related to race and sexuality.

\section{Heteronormativity, Mediterranean masculinities and colonial legacies}

The expression bunga bunga, which the media used extensively to indicate the night-time parties at the centre of the sex scandals, evokes an ironic yet powerful form of racism that constituted an effective and functional way of representing sexuality, gender and race altogether. The phrase derives from a joke Berlusconi loved to tell his friends and guests at his private parties. ${ }^{22}$ In this joke, Gaddafi, the then leader of Libya - a former Italian colony - asks Berlusconi to send two Italian delegates to his country. Berlusconi chooses to send two 'dumb' leftist Italian male politicians, who end up being captured by tribal male natives who tie them to a pole and dance around them. Their language consists only of the words 'bunga bunga', meaning rape. The head of the tribe forces the two politicians to choose between death and rape, and they choose death, thinking they will be spared the violence of rape. But they don't realise that before being killed they will inevitably end up being sexually assaulted by the savages anyway. In this racist, homophobic and neo-colonial joke, two elements are supposed to provoke the audience's laughter. One is the confirmation that the two leftist politicians are truly dumb because they trust savages. The other implication is that Berlusconi's political opponents are less than real men: they are indeed feminised, in that they lose their male identity through rape by other men. At the same time the joke invites the audience to identify with the Western civilised community, putting the savages in the category of rapists.

Berlusconi's mention of Gaddafi in the joke is not coincidental. The former Italian prime minister had a personal and political affinity with the Libyan leader. Politically, their relationship was sealed by the 2008 Treaty on Friendship Partnership and Cooperation between Italy 
and Libya, which managed disputes related to colonialism, and made Libya an ally in North Africa to supply fuel and control migrant flows (Ronzitti 2009). In public speeches and TV appearances Berlusconi frequently stressed his close personal and political friendship with Gaddafi, who was actually credited with suggesting to him the idea of holding these 'elegant' evenings, similar to those he held in his country. ${ }^{23}$ At the core of their friendship, indeed, was their mutual passion for women, and their use of young women as signs of power. This was clear, for example, during Gaddafi's lecture on the Koran in Rome, where he was participating in an FAO meeting, which he held in front of an audience of 500 charming Italian hostesses that he had paid for. ${ }^{24}$

Berlusconi's declaration of friendship with Gaddafi was an assertion of their shared virility, heterosexuality, and adherence to a model of Mediterranean masculinity characterised by hypersexual drive. In this context, Berlusconi's 'cultural' self-stereotyping as a Mediterranean male reinforced the political alliance with the then leader of a former colony. The bunga bunga joke recalled Italy's colonial role in Libyan history and at the same time shifted the colonial device of feminisation of the natives (McClintock 1995) onto savage 'others'. The racist-sexist imaginary of contemporary Italy which this jokes encapsulates draws on its colonial period, which has never really been condemned because of claims that Italian colonialism had a 'human face', and the lack of historical work on the Italian regime in Africa until very recent times (amongst others, see Sorgoni 1998, Giuliani and Lombardi-Diop 2013). It is significant that at the times of the sex scandals, leftist media and political opponents of the Italian prime minister underlined the closeness between the two leaders in order to denigrate him, repeatedly referring to the 'harem' maintained by 'sultan' Berlusconi, ${ }^{25}$ using an orientalist and colonial lexicon and imagery (Said 1978).

The display of a robust heterosexual drive is crucial to understanding the sexual imaginary of Berlusconi and his entourage. The 'bunga bunga' labelling of the night parties in Arcore based on the sex-for-money exchange can be read as a sort of ritual that wards off any spectre of a sexuality divergent from the heterosexual model. This imaginary, indeed, functions as a reassuring selfrepresentation in which the head of state is always identified as the one doing the penetration, and any possibility of his taking the so-called passive role in sexual relations had to be disavowed. The subaltern position, in fact, is associated with women and feminised men whose portrayal conveys fear of the racialised other, who is primitive and savage by definition, and expresses a deviant sexuality - not simply homosexual, but more generally ungoverned and uncontrolled.

The bunga bunga joke serves to legitimise a normative virility through racist, homophobic and transphobic tropes. ${ }^{26}$ The African, supposedly black, savage evoked in the joke embodies an unrestrained primordial instinct, frequently that of a rapist - but nonetheless possessed of the universal male sexual drive and virility. This similarly emerges from another joke that Berlusconi made in response to media reports of an alarming rise in sexual violence. Asked to comment on the issue, he replied ironically, mentioning the 'excessive' attractiveness of Italian women and the limited resources the state could offer to protect them from the risk of being raped. ${ }^{27}$ Male sexual drive is always at the centre of the picture: in this context, the figure of the rapist stands for a man who simply goes too far in his love for 'beautiful Italian girls', a clumsy seducer who has not been trained to relate civilly with the opposite sex. Seen from this perspective, the racialised native and primitive caricature of the black man in the joke emerges as a figure who embodies an 'excess' of male sex drive, as he does not recognise the differences between the sexes, and who cannot or, even worse, does not care to, distinguish between men and women. In this sexist-racist imaginary, the problem is not violence against women, which is represented as the direct outcome of a normal heterosexual drive, but rather the fact that a heterosexual white man might be penetrated by a black man. Homosociality, that is the de-sexualisation of the male-on-male bond, as an implicit pact between men of power, emerges also from the widespread homophobia and transphobia which 
characterises contemporary Italy, which by and large discourages any political figures from coming out at the price of being made a media spectacle (Busarello 2011). Hence, for example, a male politician who was caught having relations with a male-to-female transsexual apologised in public and reasserted his heterosexuality by stating that trans women are "women to the nth degree'. 28

This image of the Mediterranean male fits with the figure of the habitual consumer of sexual services (or 'final user') ${ }^{29}$ and that of the family man. Both are part of Berlusconi's self-portrayal: the former through jokes and winks, the latter through a familial iconography staged through his own media outlets. Berlusconi's unrestrained sexuality served as a framework for defining the heterosexual family and the everyday domestication of male sex drive. It is this political mood that allowed the allegedly liberal governmental forces headed by the premier's party Forza Italia to converge with the Catholic right wing. Hence, in 2007 thousands of people attended the Family Day demonstration whose slogan was 'Family According to Nature', and which protested against forms of sexuality or parenthood not conforming to the heterosexual family. ${ }^{30}$

The masculinist view of colonial history legitimises women's sexuality, agency and mobility only in the domestic realms of the family and the nation (Cheng 2010). A similar use of this nationalist rhetoric by the SNOQ committee emerged during the 2011 commemoration of 150 years since the Italian Unification, which fell a few weeks after SNOQ's first demonstration. On International Women's Day SNOQ launched a call to demonstrate on the theme of women's value and the crucial role of women in the making of the Italian nation, under the slogan Rimettiamo al mondo l'Italia (Let's bring forth Italy). As the historian Gissi remarked (2010), the association between giving birth and granting new vitality to the country was used in that period by institutional public campaigns ${ }^{31}$ promoting a model of femininity based on the figure of the white Italian mother as saviour of the nation. Consistent with the representation earlier discussed with reference to the SNOQ appeal on women's dignity, women were defined by a discursive order that positions them as whores and madonnas, linked respectively to societal decay and corruption on the one hand and caregiving and maternal altruism on the other (Peano 2012).

In this context, the figure of the migrant woman is crucial. Narratives of female freedom play a central role in Italian xenophobic discourses, such as that of the Lega Nord (Northern League) party, which was part of the political coalition ruling Italy at the times of the sex scandals. In analysing these discourses in politics and in the media, Bonfiglioli observed that representations of migrant women explicitly underlined their supposed backwardness and lack of freedom, as opposed to the inherently liberated figure of the European, white, Western woman (Bonfiglioli 2012, 79). She hence highlighted how in Italy these spheres represent privileged sites 'for the discursive and material reproduction of multiple forms of oppression that are mutually intertwined and based on differences of gender, sexuality, race/religion/nationality and class' (Bonfiglioli 2012, 79).

This racialised opposition arose during the sex scandals with reference to an underage girl of Moroccan origin, a central figure in the investigations into Berlusconi's affairs due to her frequent visits to his mansion. Karima El Mahroug, known in Milan's nightclub scene as Ruby Rubacuori (Ruby the Heart-Stealer), was taken into custody for theft in May 2010, in Milan, and later released after Berlusconi called the police station stating that she was the niece of the then Egyptian president Mubarak. In what was dubbed the 'Rubygate' trial, Berlusconi was first found guilty of abuse of power and of using the services of an underage prostitute, but then definitively acquitted in March 2015 on the grounds that he was not aware of the girl's real age at the time of their sexual relation At that time, his media represented this young woman as a symbol of social advancement: she was depicted as a protégé of his who went from poverty, violence, and the supposed backwardness of Islam, to wealth, freedom, choice and a sincere conversion to 
Catholicism (Giuliani 2013). A member of two stigmatised groups - migrant women and women consciously using sexual-economic exchange - she was nonetheless able to get money and negotiate some measure of power with the country's most powerful man. A 'Janus-faced figure of exclusion, the "victim-whore" (Peano 2012, 424), Karima represented the ambivalence of a subaltern subject who nonetheless claims spaces of choice and agency. Here, the stereotypical depiction of the figure of the escort as a shrewd and cynical self-entrepreneur using seduction and sex for money acquires a racial aspect, as clearly attested by the words of the female public prosecutor Boccassini who conducted the 'Ruby' trial. The prosecutor described this young woman as endowed with a sort of paradoxical subjectivity, stating that she was 'an intelligent, canny person endowed with that "Levantine" canniness typical of her origins, who manages to exploit precisely her status as an extra-EU foreigner' (La Repubblica, 13 May 2013). Her use of the word 'Levantine' - which means 'eastern' - reflects and conveys an orientalist prejudice and derogatory meaning: that of an astute, deceitful, unscrupulously money-oriented woman. The prosecutor's words express the effort of reconciling agency and subalternity in the context of sexual-economic exchanges which, as discussed in the article, puts choice and coercion in tension and is imbued with gendered and racialised relations of power.

\section{Conclusion}

In this article I have analysed the intense production of imaginaries, practices and public discourses that have developed around the events that led to the end of Berlusconi's mandate. I have identified the competing discourses on women's sexual freedom at the time of his sex scandals as a crucial site of political and cultural dispute in Italy. These discourses focused primarily on women's choices and behaviour, in particular on the use of their own sexuality to get money or power. In my argument I have tried to foreground the multiplicity of devices at work in these public debates about gender, freedom and sexuality and the way they intertwine with class, race and generation.

The episodes revolving around sex and power discussed throughout the article have foregrounded the convergence between conservative and neoliberal views on gender. Neoliberal narratives that refer to women's self-management of the body and the use of sexuality and seduction for their own ends require a parallel conservative narrative on the unchangeable gender differences that imply an imbalance of power. To combat this view, progressive movements on women's rights against sexism such as SNOQ used an oppositional narrative contrasting respectable women and women who use sexual-economic exchange. To discuss this opposition I have referred to changes in the sphere of work and the ways in which features historically attributed to women have become the core for new forms of exploitation in which a divergent distinction between escorts and caregivers is misleading.

To better understand the production of gender imagery that was at stake at the time of the public debates on the then premier Berlusconi's sexual conduct, I have shifted the focus from women to discourses on masculinity. While the debates insisted on the issue of women's behaviour, I have foregrounded the peculiar construction of masculinity fostered by the premier himself. Through an analysis of some of Berlusconi's narratives about gender, including the more famous and controversial jokes and comments related to gender relations, I have highlighted how a male hegemonic Mediterranean masculinity draws on a narrative in which colonial and racist commonplaces overlap with homophobia. Finally I have discussed 'Ruby-gate', as it revealed that the discourse on women's sexual freedom remained trapped within the frame of polarised images of good and bad women, and how the debate on women's choice and freedom was traversed by implicit racist views. 
Analysing a particular historical moment in which the debate on sex and power has flourished, my argument is meant to demonstrate the complexity of cultural constructions of femininity and masculinity and the often unrecognised intersection of sexism and racism in the Italian political/ public scenario.

\section{Acknowledgements}

I wish to thank Giovanna Zapperi with whom I have discussed and reflected on the issues presented in this article and the editors and reviewers of this special issue for their accurate and patient revision.

\section{Notes on contributor}

Alessandra Gribaldo teaches anthropology at the University of Bologna. She has published in edited books and journals (including American Ethnologist, Population and Development Review, Studi Culturali) and she is the author of the books Boundaries Within (2017, edited with F. Decimo, Springer), Lo schermo del potere. Femminismo e regime della visibilità (2012, with G. Zapperi, Ombre Corte), La produzione del genere (2010, edited with V. Ribeiro Corossacz, Ombre Corte), and La Natura Scomposta. Riproduzione assistita, genere, parentela (Sosella 2005).

\section{Notes}

1. The term 'escort' refers to a man or more frequently a woman who is paid to go out to social events with another person as their partner and possibly to have sex. In Italy its use became common to refer to women involved in Berlusconi's sex scandals.

2. The term velina (plural: veline) emerged at the end of the 1980s to indicate the silent, scantily-clad showgirls who were tasked with presenting the hosts with the veline (journalistic jargon for news of the day) on a popular satirical show broadcast on one of Berlusconi's TV channels. On the role played by women's bodies in the production of Berlusconi's media regime, see Gribaldo and Zapperi 2012.

3. Arcore is a municipality next to Milan.

4. The 'Processo escort' is still ongoing at the court of Bari, and so is the investigation 'Ruby Ter' on alleged corruption of witnesses at the court of Milan.

5. Berlusconi's first electoral term began in 1994, and his last one ended in 2011.

6. LGBTQI stands for Lesbian, Gay, Bisexual, Transgender, Queer, Questioning and Intersex.

7. Sannino, C. and C. Bonini. 2009. "'Silvio sapeva tutto di me ecco perchè non pu dire di avermi dimenticata"'. La Repubblica 25 June. http://www.repubblica.it/2009/06/sezioni/politica/berlusconidivorzio-10/parla-patrizia/parla-patrizia.html

8. 'Intervista choc di Terry De Nicoló'. Il fatto quotidiano. 17 September 2011. http://www. ilfattoquotidiano.it/2011/09/17/intervista-choc-di-terry-de-nicolo/158125

9. The word postfeminist is a contested term entailing different and sometimes opposite meanings (Gill 2007). Here I use it to refer to discourses that take for granted an achieved gender equality and represent a conservative social retrenchment and 'hostility to feminism in any of its old or newer forms' (Gill and Scharff 2011, xi).

10. 'Berlusconi e la Battuta sulla precaria: "Con quel sorriso sposi un milionario"'. Il Corriere della Sera. 13 March 2008. http://www.corriere.it/politica/08_marzo_13/berlusconi_farmacisti_934172e4-f0ff$11 \mathrm{dc}-9 \mathrm{~d} 4 \mathrm{f}-0003 \mathrm{ba99}$ c667.shtml?refresh_ce-cp

11. See a young woman's testimony in a video interview ('Barbara Montereale intervista integrale'. https:// www.youtube.com/watch?v=BvNx6Iazqh8).

12. The Merlin law dates back to 1958. For its historical contextualisation, see Bellassai 2006.

13. Newspapers reported the use of the nickname 'malefic dwarf' to refer to Berlusconi in a WhatsApp chat by a group of girls attending his private dinners (see for example Colonnello, P. 2015. 'Arcore assediata dale Olgettine, la classifica delle più accanite'. La Stampa 26 March. http://www.lastampa.it/2015/03/26/ italia/cronache/arcore-assediata-dalle-olgettine-la-classifica-delle-pi-accanite-b6F3VDINgz4s4JmSh5TsvL/ premium.html). Two girls who decided to run away from the mansion described the grotesque scene in 
which during a dinner a group of girls was asked to kiss a statue of Priapus ('Caso Ruby. Chiara: "baciavano il pene della statua di Priapo. Io e Ambra scioccate"'. Il Fatto Quotidiano. 7 May 2012. http://www.ilfattoquotidiano.it/2012/05/07/ruby-chiara-baciavano-pene-della-statua-priapo-ambra-scioccate/ 221139).

14. Berizzi, P., C. Bonini, G. De Matteis and G. Foschini. 2009. “'Cosí ci reclutavano per le feste di Berlusconi”". La Repubblica 20 June. http://tv.repubblica.it/dossier/10-domande/esclusivo-cosi-cireclutavano-per-le-feste-di berlusconi/34132/34469

15. De Gregorio, C. 'Le altre donne'. L'Unitá 18 January 2011. http://concita.blog.unita.it/le-altre-donne1.266857

16. 'Il riscatto delle donne, ma non solo. Oltre un milione di persone in 100 piazze'. Il Fatto Quotidiano 13 February 2011. https://www.ilfattoquotidiano.it/2011/02/13/da-trieste-a-palermo-da-bari-a-pesaro-sonogia-decine-di-migliaia-le-donne-in-piazza/91829/

17. Amabile, F. 2011. 'Se non ora quando qual é la storia del movimento?' La Stampa 12 December. http:// www.lastampa.it/2011/12/12/cultura/domande-e-risposte/se-non-ora-quando-qual-e-la-storia-del-movi mento-hG9nZnSS26MhzETsQge8AP/pagina.html

18. The correlation between the lack of dignity and subalternity to male power with prostitution was evident from the banner displayed during the 2011 demonstration in the crowded square in Rome that declared: 'Do not call me escort: I am a prostitute, do not call me prostitute: I am a slave.' 'Il riscatto delle donne, ma non solo. Oltre un milione di persone in 100 piazze' Il Fatto Quotidiano 13 February. https://www. ilfattoquotidiano.it/2011/02/13/da-trieste-a-palermo-da-bari-a-pesaro-sono-gia-decine-di-migliaia-ledonne-in-piazza/91829/

19. The notion of 'reproductive work' is commonly used in feminist debates to highlight how in a capitalist system the labour that women do in the domestic sphere, albeit fundamental for social reproduction, is not paid and therefore goes unrecognised. See, among others, Federici (1980).

20. Razzi, M. 2012. 'Infermiere e agenti segreti. Arcore meglio di Neverland'. La Repubblica. 23 May. http://inchieste.repubblica.it/it/repubblica/rep-it/2012/05/23/news/infermiere_e_agenti_segreti_arcore_ meglio_di_neverland-35733749/

21. Sexy Italian comedy is a sub-genre of Italian comedy, featuring male comedians and beautiful scantily clad female actresses, which drew large audiences also through the emerging private TV channels of the time.

22. “"Morire o Bunga Bunga?". Silvio Berlusconi e la barzelletta con protagonist quei "due sfigati” Bondi e Cicchitto",. Huffington Post. 27 September 2015. http://www.huffingtonpost.it/2015/09/27/silvioberlusconi-barzelletta-bunga-bunga_n_8202924.html

23. Colaprico, P., G. D'Avanzo, and E. Randacio. 2011. 'Tutte nude al bunga bunga e quand'ero in questura Silvio aveva paura'. La Repubblica 18 February. http://www.repubblica.it/politica/2011/02/18/news/ verbali_18_febbraio-12597624/

24. Caccia, F. and F. Peronaci. 2009. The article reports that the young women were recruited through a public relations agency and each given 60 euros and a copy of the Koran.

25. Gomez P. and M. Lillo. 2009. 'L'harem di Berlusconi'. L'Espresso 28 May. http://espresso.repubblica.it/ palazzo/2009/05/28/news/l-harem-di-berlusconi-1.35392

26. As systematically underlined by the Italian media when stressing the ethnicity of men who sexually assault women only when he is a foreigner (Ribeiro Corossacz 2013).

27. 'We would need as many soldiers as there are beautiful Italian girls, I doubt we will ever manage it...' ('Berlusconi sugli stupri, gaffe e polemiche'. Corriere della Sera 25 January 2009. http://www.corriere.it/ politica/09_gennaio_25/berlusconi_libia_stupri_soldati_b7c89ae2-eae7-11dd-9c57-00144f02aabc.shtml)

28. De Gregorio, C. 2011. 'Le confessioni di Marrazzo: "Ecco perché andavo in via Gradoli”'. La Repubblica 15 August. http://www.repubblica.it/politica/2011/08/15/news/intervista_marrazzo-20450866/

29. This expression was used by Berlusconi's lawyer meaning that he never paid women for sex and was not involved in requests for sexual services (Martirano, D. 2009. 'Il premier? Non ha mai pagato le donne'. Corriere della Sera 18 June. http://www.corriere.it/politica/09_giugno_18/martirano_ghedini_inchiesta_bari_caef95e4-5bc6-11de-b8d9-00144f02aabc.shtml)

30. 'Family Day, in piazza il mondo cattolico. "No ai Dico, noi il nocciolo della societá"'. La Repubblica 12 May 2007. http://www.repubblica.it/2007/05/sezioni/politica/coppie-di-fatto-8/piazza-gremita/ piazza-gremita.html

31. Gissi analyses as examples a video spot made by the Ministry of Defence and the 5-metre banner displayed on the historical palace of Università Popolare di Roma in March 2011. 


\section{References}

Bellassai, S. 2006. La legge del desiderio. La legge Merlin e l'Italia degli anni Cinquanta. Milan: Carocci. Belpoliti, M. 2009. Il corpo del capo. Parma: Guanda.

Bernstein, E. 2007. Temporarily Yours: Intimacy, Authenticity and the Commerce of Sex. Chicago: University of Chicago Press.

Bonfiglioli, C. 2012. 'Razzismo, sessismo, nazionalismo. Dibattiti femministi e critica post-coloniale nel contesto italiano'. In La razza al lavoro, edited by A. Curcio, and M. Mellino, 91-115. Rome: Manifestolibri.

Busarello, R. 2011. 'L'Italia del patto omosociale'. 27 September, zeroviolenzadonne.org.

Caccia, F., and F. Peronaci 2009. 'Gheddafi invita 100 hostess e fa lezione'. Corriere della Sera 16 November. http://www.corriere.it/cronache/09_novembre_16/geddafi_hostess_0ac99aa2-d27d-11dea0b4-00144f02aabc.shtml/

Cheng, S. 2010. On the Move for Love. Migrant Entertainers and the US Military in South Korea. Philadelphia: University of Pennsylvania Press.

Corso, C., and S. Landi 1991. Ritratto a tinte forti. Florence: Giunti.

Dei, F. 2011. 'Pop-politica: le basi culturali del Berlusconismo'. Studi Culturali 8 (3): 471-489.

Dominijanni, I. 2009. 'Ragazze immagine'. Il Manifesto 24 June.

Dominijanni, I. 2014. Il trucco. Sessualità e biopolitica nella fine di Berlusconi. Rome: Ediesse.

Fantone, L. 2007. 'Precarious Changes: Gender and Generational Politics in Contemporary Italy'. Feminist Review 87: 5-20.

Federici, S. 1980. 'Wages against housework'. In The Politics of Housework, edited by E. Malos, 217-225. London: Allison \& Busby.

Fraser, N. 2013. Fortunes of Feminism. From State-Managed Capitalism to Neoliberal Crisis. LondonNew York: Verso.

Galetto, M., C. Lasala, S. Magaraggia, C. Martucci, E. Onori, and C. Ross 2009. 'Feminist Activism and Practice: Asserting Autonomy and Resisting Precarity'. In Resisting the Tide: The Berlusconi Years, edited by C. Ross, and D. Albertazzi, 190-203. London: Bloomsbury.

Gill, R. 2007. 'Postfeminist Media Culture: Elements of a Sensibility'. European Journal of Cultural Studies 10 (2): $147-166$.

Gill, R. 2008. 'Culture and Subjectivity in Neoliberal and Postfeminist Times'. Subjectivity 25: 432-445.

Gill, R., and C. Scharff, eds. 2011. New Femininities. Postfeminism, Neoliberalism and Subjectivity. New York: Palgrave Macmillan.

Gissi, A. 2010. 'Il corpo della nazione in festa. Alcune considerazioni su genere e comunicazione in occasione dei 150 anni dell'Unità d'Italia'. Genesis IX 2: 221-228.

Giuliani, G. 2013. 'Per un'analisi intersezionale dell'orientalismo nella televisione italiana contemporanea'. In Orientalismi italiani, edited by G. Proglio, Vol. 3, 190-208. Castagnito: Antares.

Giuliani, G., and C. Lombardi-Diop 2013. Bianco e nero. Storia dell'identità razziale degli italiani. Milan: Le Monnier.

Gribaldo, A., and G. Zapperi 2012. Lo schermo del potere. Femminismo e regime della visibilità. Verona: Ombre Corte.

Hakim, C. 2011. Honey Money: The Power of Erotic Capital. London: Allen Lane.

Hoang, K.K. 2015. Dealing in Desire. Asian Ascendancy, Western Decline, and the Hidden Currencies of Global Sex Work. Berkeley: University of California Press.

Kempadoo, K., and J. Doezema, eds. 1998. Global Sex Workers. Rights, Resistance and Redefinition. London: Routledge.

MadhokS., A. Phillips, and K. Wilson, eds. 2013. Gender, Agency and Coercion. New York: Palgrave Macmillan. Mathieu, N.C. 2013. L'anatomie politique. Catégorisations et idéologies du sexe. Paris: Éditions iXe.

Marazzi, C. 1999. Il posto dei calzini. La svolta linguistica dell'economia e i suoi effetti sulla politica. Turin: Bollati Boringhieri.

Mahmood, S. 2005. Politics of Piety. The Islamic Revival and the Feminist Subject. Princeton: Princeton University Press. 
McLintock, A. 1995. Imperial Leather. Race, Gender and Sexuality in Colonial Context. London-New York: Routledge.

McRobbie, A. 2009. The Aftermath of Feminism: Gender, Culture and Social Change. London: Sage.

Morini, C. 2007. 'The Feminization of Labour in Cognitive Capitalism'. Feminist Review 87: 40-59.

Morini, C. 2010. Per amore o per forza. Femminilizzazione del lavoro e biopolitiche del corpo. Verona: Ombre Corte.

Nadotti, M. 2011. 'Le contraddizioni e il no alla crociata'. Corriere della Sera 7 February.

Pasquino, G. 2007. 'The Five Faces of Silvio Berlusconi. The Knight of Anti-Politics'. Modern Italy 12 (1): $39-54$.

Peano, I. 2012. 'Excesses and Double Standards: Migrant Prostitutes, Sovereignty and Exceptions in Contemporary Italy'. Modern Italy 17 (4): 419-432.

Pheterson, G., ed. 1989. A Vindication of the Rights of Whores: The International Movements for Prostitutes' Rights. Seattle: Seal.

Phillips, A. 2013. 'Does the Body Make a Difference?' In Gender, Agency and Coercion, edited by S. Madhok, A. Phillips, and K. Wilson, 143-156. New York: Palgrave Macmillan.

Pitch, T. 2011. 'Il corpo delle donne non è della nazione'. Il Manifesto 26 February.

Ribeiro Corossacz, V. 2013. 'L'intersezione di razzismo e sessismo. Strumenti teorici per un' analisi della violenza maschile contro le donne nel discorso pubblico sulle migrazioni'. Antropologia 15: 109-129.

Romagnoli, B. 2014. Irriverenti e libere. Femminismi nel nuovo millennio. Rome: Editori Riuniti.

Ronzitti, N. 2009. 'The Treaty on Friendship, Partnership and Cooperation between Italy and Libya: New Prospects for Cooperation in the Mediterranean?' Bulletin of Italian Politics 1 (1): 125-133.

Rubin, G. 1975. 'The Traffic in Women: Notes on the "Political Economy" of Sex'. In Toward an Anthropology of Women, edited by R. Reiter, 157-210. New York: Monthly Review Press.

Said, E. 1978. Orientalism. London: Routledge.

Signorelli, A. 2011. 'Le ambigue pari opportunità e il nuovo maschilismo'. In Berlusconismo. Analisi di un sistema di potere, edited by P. Ginsborg, and E. Asquer, 207-221. Rome Laterza.

Sorgoni, B. 1998. Parole e corpi: antropologia, discorso giuridico e politiche sessuali interrazziali nella colonia Eritrea, 1890-1941. Naples: Liguori.

Tabet, P. 2004. La grande beffa. Sessualità delle donne e scambio sessuo-economico. Rome: Rubbettino.

Yuval-Davis, N. 1997. Gender and Nation. London: Sage.

\section{Italian summary}

L'articolo è una riflessione a partire dai cosidetti 'scandali sessuali' che hanno riguardato il primo ministro Silvio Berlusconi durante gli ultimi anni del suo governo (2009-2011) e riempito le colonne dei giornali e i fascioli giudiziari. I discorsi politici e le interpretazioni mediali sulla libertà delle donne del periodo rappresentavano i generi attraverso l'erotizzazione del potere. Il dispiegarsi di rappresentazioni post-femministe e stereotipate delle relazioni di genere andavano a formare un quadro complesso e ambivalente sull'agency e la sessualità femminile riproducendo la retorica egemonica leoliberista che posiziona la libertà e l'emancipazione nel mercato. L'autodeterminazione delle donne nell'uso del proprio corpo dunque si sovrapponeva alla ratificazione degli squilibri di potere tra generi. Questa narrazione aveva degli accenti di classe e razza, in quanto si articolava attraverso le opposte immagini delle donne bianche italiane accudenti e rispettabili contro ciniche giovani donne e migranti che usavano il loro corpo come una risorsa nello scambio sessuo-economico con uomini che occupavano posizioni di potere. Attraverso la riflessione femminista sul lavoro rintraccio e tratto l'uso delle nozioni di scelta e libertà in questi discorsi. Spostando l'attenzione dal comportamento delle donne all'analisi della specifica immagine di mascolinità portata avanti dall'ex premier l'articolo sottolinea come razzismo, eredità coloniale, e omofobia siano implicate in un immaginario di genere culturalmente $\mathrm{e}$ storicamente connotato. 